Ahmed Elhefnawy

Space Technology Center Kobry El koba, Cairo

Egypt

Ali Elmaihy

Department of Mechanical Power and Energy

Military Technical College Kobry El koba, Cairo

Egypt

\section{A University Small Satellite Thermal Control Modeling and Analysis in the Post-Mission Phase}

This work includes the thermal control analysis of a small spacecraft in the post-mission phase. The satellite internal component distribution has been modified to fulfill all thermal requirements when using a passive thermal control system. In the post-mission phase, the satellite will be used by the radio Amateur Satellite Corporation (AMSAT) community as a transponder, fully using the AMSAT payload that will maintain active and shall last at least 2 years. Thermal Desktop software is introduced for the mentioned spacecraft. The final analysis predictions show that the passive thermal control system maintains all satellite element's temperatures within their temperature limits. The temperature variation of $+X$ solar panel is $75{ }^{\circ} \mathrm{C}$ which is less than experienced by $+Z$ and $-Z$ panels, which are $100{ }^{\circ} \mathrm{C}$. The temperature change on equipment agrees with their panels. Compared with a specialized thermal analysis, software package (ESATAN-TMSS) verified the integrity of the results.

Keywords: Aerospace Engineering, satellite thermal control, modeling.

\section{INTRODUCTION}

A thermal control system (TCS) is a significant issue in both the designing and manufacturing processes of a spacecraft. It emphasizes the appropriate operation of the satellite in the operating temperature ranges in its orbit [12]. Several analytical calculations analyzing spacecraft thermal control have been carried out, for instance, the Fourier analysis [3] and techniques of the linearization method [4-7]. Anh. et al. [8-10] extended the equivalent linearization method to the thermal analysis of satellite using both conventional and dual criteria of linearization. The analytical investigation of satellite thermal control is very difficult due to complicated nonlinear terms existing in the thermal models. Analytical analyses are only beneficial for simple geometric case studies which are not representative of real cases [11]. So, recent complex numerical algorithms were developed and incorporated for satellite thermal problems in commercial software [1,12]. The definition of small satellites is not clear and different organizations define small satellites differently [13].

Table 1 summarizes a number of these definitions. Based on Surrey Space Centre, small-satellite classification [14], the following groups were identified; nanoand pico-satellites $(<10 \mathrm{~kg})$, micro-satellites $(10-100$ $\mathrm{kg})$, mini-satellites $(100-500 \mathrm{~kg})$, interplanetary small missions $(<500 \mathrm{~kg})$.

Certain requirements originating in small-satellite designs due to limited mass and power, limited volume for payload, and housekeeping systems generate major challenges for small satellite thermal control system design and analysis [16].

University class satellites are truly international with 40

Received: June 2021, Accepted: August 2021

Correspondence to: Ali Elmaihy, Department of

Mechanical Power and Energy, Military Technical

College Kobry El koba, Cairo, Egypt.

E-mail: ali.elmaihy@mtc.edu.eg

doi:10.5937/fme2104014E

(C) Faculty of Mechanical Engineering, Belgrade. All rights reserved nations from 6 continents providing spacecraft. The USA, Europe, Japan have built $75 \%$ of all the university-class satellites $[17,18]$. Several studies concerning small satellite TC have been conducted by universities (Table 2) [19-33].

Most literature showed that the spacecraft TCS is primarily passive; however, uses heaters in critical locations [34].

Table 1. Definitions for Small Satellites

\begin{tabular}{|l|l|}
\hline Organization & Definition \\
\hline \multirow{2}{*}{ ESA [13] } & Small 350-700 kg \\
& Mini 80-350 kg \\
& Micro 50-80 kg \\
\hline \multirow{2}{*}{ EADS [13] } & MiniXL 1,000-1,300 kg \\
& Mini 400-700 kg \\
& Micro 100-200 kg \\
\hline CNES [13] & Mini 500 kg*Payload (P/L) \\
& Micro 1,200 kg*Payload(P/L) \\
\hline & Pico-Satellite 0.01-1 kg \\
NASA [15] & Nano-Satellite 1-10 kg \\
& Micro-Satellite 10-100 kg \\
& Mini-Satellite 100-180 kg \\
\hline
\end{tabular}

Assessing the thermal characteristics of a picky contestant design includes the implementation of a complicated and costly numerical simulation. The structure of the proposed system is often represented using a mesh during simulations. Then, numerical solution of the governing equations is carried out by using different schemes namely; finite-difference time-domain (FDTD), finite element (FEM), or moments (MoM) methods boundary conditions related to the studied problem must be set.

The thermal models have been validated with the assistance of actual tests or with results obtained from other software. Corpino et al. [35] proposed finite difference schemes to model the thermal performance of LEO satellites. Their results were validated using ESATAN-TMS modeling software. Diaz-Aguado et al. [36] carried out the thermal design of the FASTRAC Nanosatellite considering vacuum conditions. They used FEM Results to validate their results. 
Table 2 Summary of university activities in small satellites thermal control

\begin{tabular}{|c|c|c|c|c|c|c|}
\hline No & University & Country & Ref. & Satellite name & $\begin{array}{c}\text { Thermal Control System } \\
\text { type }\end{array}$ & Software used \\
\hline 1 & Applied Sciences Aachen & sermany & {$[19]$} & compass-1 & Passive & ANSYS \\
\hline 2 & Liège University & Belgium & {$[20]$} & OUFTI-1 & $\begin{array}{l}\text { Passive with an elec-tric } \\
\text { heater for the battery }\end{array}$ & ESATAN \\
\hline 3 & San Jose State University & JSA & {$[21]$} & -- & Passive & Thermal Desktop \\
\hline 4 & Istanbul Technical University & Turkey & {$[22-23]$} & Turksat-3U & Passive & Therm-XL \\
\hline 5 & $\begin{array}{l}\text { The Pennsylvania State } \\
\text { University }\end{array}$ & JSA & {$[24]$} & OSIRIS-3U & Passive & COMSOL \\
\hline 6 & Politecnico di Milano & taly & {$[25]$} & ESEO & $\begin{array}{l}\text { Passive with an electric } \\
\text { heater for the battery }\end{array}$ & ESATAN \\
\hline 7 & $\begin{array}{l}\text { National Institute of Space } \\
\text { Research }\end{array}$ & Brazil & {$[26]$} & Amazonia-1 & $\begin{array}{l}\text { Passive heaters regulated } \\
\text { by software via } \\
\text { thermistors }\end{array}$ & Thermal Desktop \\
\hline \multirow[t]{2}{*}{8} & \multirow[t]{2}{*}{ Toronto University, Canada } & \multirow[t]{2}{*}{ Fanada } & {$[27-29]$} & $\begin{array}{l}\text { canX-4 } \\
\text { canX-5 }\end{array}$ & \multirow[t]{2}{*}{ Passive } & \multirow{2}{*}{$\begin{array}{l}\text { Siemens' } \\
\text { NX } 8\end{array}$} \\
\hline & & & \begin{tabular}{|l|}
{$[30]$} \\
\end{tabular} & canX-7 & & \\
\hline 9 & Von Karman Institute & Belgium & [31] & QARMAN & Passive & ESATAN \\
\hline 10 & $\begin{array}{l}\text { Delft University of } \\
\text { Technology }\end{array}$ & Netherlands & [32] & Delffi & Passive & ESATAN \\
\hline 11 & Missouri University & JSA & {$[33]$} & $\begin{array}{l}\text { MR sat } \\
\text { MRS sat }\end{array}$ & Passive & Thermal Desktop \\
\hline
\end{tabular}

Bulut et al. [37] investigated the thermal characteristics of a CubeSat using FEM by investigating different solar panel configurations. To our knowledge, there is no standard method to carry out the design of a $\mathrm{Cu}-$ beSat Thermal Control System using highly developed computation, especially for passive thermal systems [11].

The European Student Earth Orbiter (ESEO) spacecraft [25] was selected to carry this work. It was established by candidates of different universities sponsored by the European Space Agency (ESA) education office. ESEO is LEO micro-satellite mission. This satellite has five mission stages: launch and early operations; operational; extended stage; post-mission and finally dispo-sal. This study is concerned with the post-mission stage that begins after the extended stage or the operational stage and shall last at least 2 years. In this stage the spacecraft will be used by the radio Amateur Satellite Corporation (AMSAT) community as a transponder, fully using the AMSAT payload that will remain active. The satellite will be ordered to obtain a safe configuration, permitting it to survive without help from the ground.

The novelty of this paper is to enrich the thin literature on the thermal design of small-sized satellites. Since detailed thermal control modeling and analysis are rare, the work might give an insight to fellow small-size satellite developers. ESEO thermal control system was initially designed as active thermal control and thermal analysis was performed using the ESATAN software package [25]. This paper includes an alternative means for the thermal control system to be passive by using tapes, coatings, radiators, and Multi-Layer Insulation (MLI) applied to the satellite to regulate the interaction between the spacecraft and its surroundings. A detailed thermal model for ESEO satellite has been created using Thermal Desktop software [38]. Results were partially verified using the published data of ESEO for the external radiation absorbed by the satellite.

The work is arranged as follows: first, the selected satellite for study, ESEO is described; then, the thermal analysis model based on a nodal lumped parameter method is elaborated; finally, results, discussions, and conclusions are given.

\section{ESOE DESCRIPTION}

Fig. 1 and 2 show the external and internal views respectively for the satellite under investigation. The satellite is a cuboid shape with six structural panels, two deployable and one fixed solar panel. Its dimensions are $967 \times 750 \times 680 \mathrm{~mm}$ and its mass is less than $100 \mathrm{~kg}$.

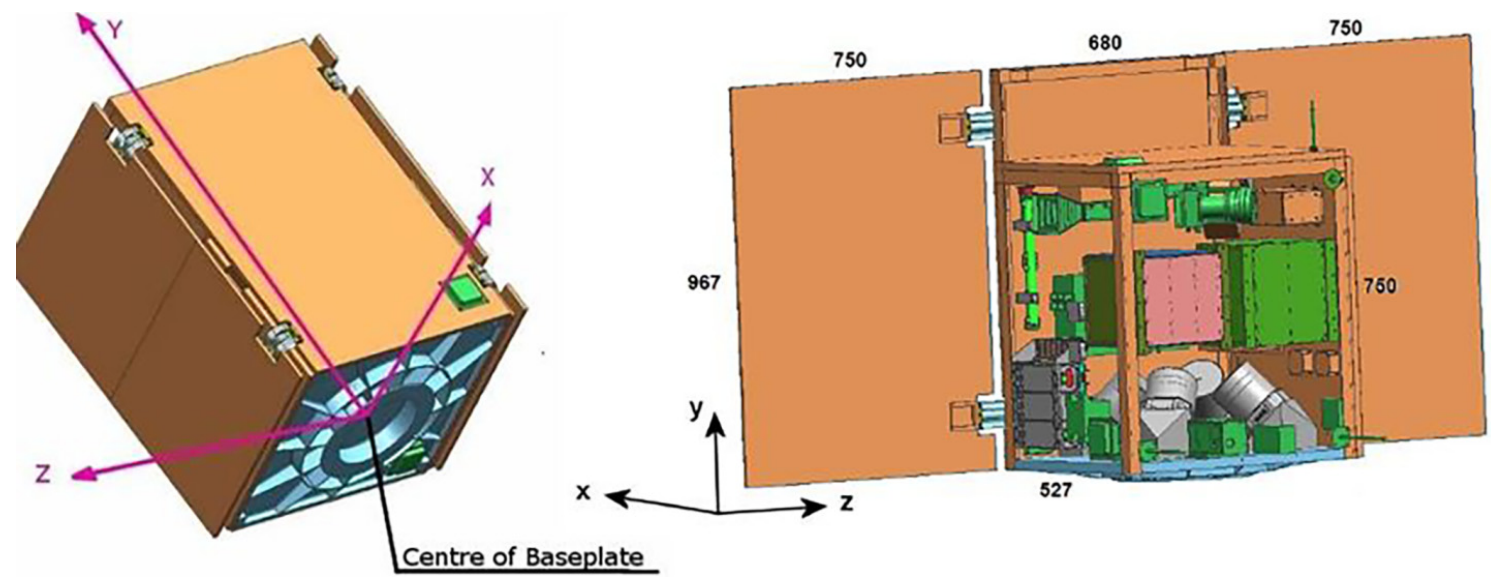

Fig. 1 External view of ESEO satellite[25] 


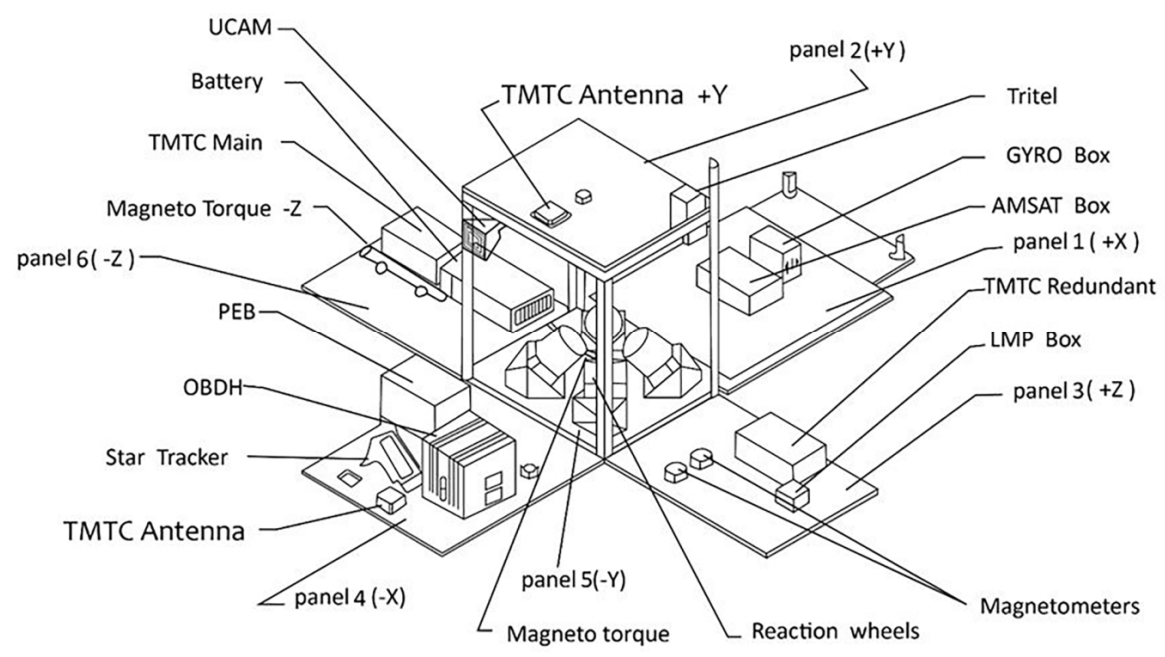

Fig. 2 Internal view of ESEO satellite adapted from [25]

The mission was based on sun-synchronous orbit with an altitude of $520 \mathrm{~km}$ and an inclination of $97.48^{\circ}$ with Local Time of Ascending Node (LTAN) 10:30. Satellite systems/components are given in Table 3 .

Table 3 ESEO systems / components [25]

\begin{tabular}{|l|l|l|}
\hline No & Equipment & System \\
\hline 1 & AMSAT & Payload \\
\hline 2 & $\begin{array}{l}\text { Tridimensional Telescope } \\
\text { dosimeter (Tri-Tel S) }\end{array}$ & Payload \\
\hline 3 & Micro camera (UCAM) & Payload \\
\hline 4 & $\begin{array}{l}\text { Langmuir plasma diagnostic } \\
\text { probe (LMP) }\end{array}$ & Payload \\
\hline 5 & $\begin{array}{l}\text { Telemetry and Telecommand } \\
\text { system (TMTC) } \\
\text { Telemetry and Telecommand } \\
\text { Antenna (TMTC Antenna) }\end{array}$ & $\begin{array}{l}\text { Communication } \\
\text { system }\end{array}$ \\
\hline 6 & $\begin{array}{l}\text { Electric Power System control } \\
\text { unit (EPS PEB) } \\
\text { Battery }\end{array}$ & $\begin{array}{l}\text { Electric power } \\
\text { system }\end{array}$ \\
\hline 7 & $\begin{array}{l}\text { Magnetion Wheel } \\
\text { Magnetometer } \\
\text { Star Tracker }\end{array}$ & ADCS \\
\hline 8 & On-Board data Handling (OBDH) & $\begin{array}{l}\text { On-board data } \\
\text { handling }\end{array}$ \\
\hline
\end{tabular}

\section{THERMAL ANALYSIS MODEL}

\subsection{Thermal Control Design}

ESEO thermal control system was initially designed as active thermal control and thermal analysis was per-formed using ESATAN software package [25]. The satellite has been partially modified by changing the placement of the internal components and controlling external radiation exchange by managing the exterior thermo-optical properties. All spacecraft equipment is redistributed on the six structural panels to meet all thermal requirements when a passive TCS instead of an active TCS was used. The distribution of the internal components on different structure panels is shown in Table A.1 in Appendix A.

\subsection{Thermal Energy Balance}

The thermal modeling is based on a nodal or lumped parameter method. In this method, the satellite is divi- ded into several regions, assumed isothermal, which are called nodes. These nodes exchange heat among each other by conduction and radiation. The external nodes exchange heat with the surroundings via radiation. The temperature of each node is the result of these interactions. The energy balance on node $\mathrm{i}$ is expressed by Equation (1) [39]

$$
\begin{aligned}
m_{i} c_{i} \frac{d T_{i}}{d t} & =\dot{Q}_{\text {external }, i}+\dot{Q}_{\text {dissipated }, i}-\dot{Q}_{\text {emitted }, i} \\
& -\dot{Q}_{\text {conductive }, i j}-\dot{Q}_{\text {radiative }, i j}
\end{aligned}
$$

where: $m_{i} c_{i}$ is the thermal mass $[\mathrm{J} / \mathrm{K}] ; \dot{Q}_{\text {dissipated }, i}$ is the total heat rate dissipated by the satellite equipment [W]. It is calculated by summation of the operating components of heat dissipated during the considered mission as shown in Table A.1; $\dot{Q}_{\text {emitted }, i}$ is the heat rate emitted from the satellite [W] as given by Equation (2).

$$
\dot{Q}_{\text {emitted }, i}=\sigma \varepsilon_{i} A_{\text {radiator }, i} T_{i}^{4}
$$

where $\sigma$ is the Stefan-Boltzmann constant $\left[\mathrm{W} / \mathrm{m}^{2} \mathrm{~K}{ }^{4}\right]$, $\mathrm{A}_{\text {radiator, }} \mathrm{i}$ the available radiator area, $\varepsilon_{\mathrm{i}}$ surface emissivity; $Q_{\text {external, i }}$ is external heat rate experienced in LEO, given by Equation (3).

$$
\dot{Q}_{\text {external }, i}=\dot{Q}_{\text {solar }}+\dot{Q}_{\text {Albedo }}+\dot{Q}_{\text {Planetary }}
$$

The conductive heat rate, $\mathrm{Q}_{\text {conductive, } \mathrm{ij} \text {, and radiative }}$ heat rate, $Q_{\text {radiative,ij }}$ exchange between nodes is given by equations (4), (5) respectively [40].

$$
\begin{gathered}
\dot{Q}_{\text {conductive }, i j}=\sum_{j=1}^{n} K_{i j}\left(T_{i}-T_{j}\right) \\
\dot{Q}_{\text {radiative }, i j}=\sum_{j=1}^{n} R_{i j}\left(T_{i}^{4}-T_{j}^{4}\right)
\end{gathered}
$$

The conductive and radiative heat exchange factors are defined as:

$$
\begin{gathered}
K_{i j}=\frac{-k A_{i}}{d x} \\
R_{i j}=A_{i} F_{i j} \varepsilon_{i j}
\end{gathered}
$$


where $K_{i j}$ is conductive heat rate exchange factor between nodes $i$ and $j[\mathrm{~W} / \mathrm{K}] ; R_{i j}$ is radiative heat rate exchange factor between nodes $i$ and $j\left[\mathrm{~W} / \mathrm{K}^{4}\right] ; \mathrm{A}_{\mathrm{i}}$ is the nodal area $\left[\mathrm{m}^{2}\right] ; d x$ is the distance between two adjacent nodes $[\mathrm{m}] ; \varepsilon_{i j}$ is the emissivity between nodes $\mathrm{i}$ and $\mathrm{j} ; \mathrm{T}_{\mathrm{i}}$ and $T_{j}$ are the temperatures of nodes $i$ and $j$, respectively $[\mathrm{K}] . \mathrm{F}_{\mathrm{ij}}$ is the view factor between nodes $\mathrm{i}$ and $\mathrm{j}$ which is defined as the fraction of radiation leaving surface $i$ that is intercepted by surface $\mathrm{j}$

Then, Equation (1) becomes:

$$
\begin{aligned}
m_{i} c_{i} \frac{d T_{i}}{d t}= & \dot{Q}_{\text {external }, i}+\dot{Q}_{\text {dissipated }, i}-\sigma \varepsilon_{i} A_{\text {radiator }, i} T_{i}^{4} \\
& -\sum_{j=1}^{n} K_{i j}\left(T_{i}-T_{j}\right)-\sum_{j=1}^{n} R_{i j}\left(T_{i}^{4}-T_{j}^{4}\right)
\end{aligned}
$$

\subsection{Geometry Creation and Methodology}

The first step in model creation is defining the external geometry. The spacecraft geometry consists of a cuboid structure (six structure panels) and three solar panels (one fixed and two deployable panels). Each external solar or structural panel was created in the thermal desktop software by a rectangle. From structure designers, the external panels are designed of two different materials-honeycomb and aluminum 2024. Aluminum was used for panels number one, four, and five (in the directions $+\mathrm{X},-\mathrm{X}$, and $-\mathrm{Y}$ respectively). For design reasons, the aluminum panels have a thickness of $20.6 \mathrm{~mm}$. Honeycomb panels were used for panels number two, three, and six (in the directions $+Y,+Z$, and $-Z$ respectively) and the three solar panels. The body or equipment panels have a shell thickness of 0.3 $\mathrm{mm}$ and a core thickness of $20 \mathrm{~mm}$ with a total thickness of $20.6 \mathrm{~mm}$. The solar panels have a shell thickness of $0.3 \mathrm{~mm}$ and a core thickness of $13 \mathrm{~mm}$ with a total thickness of $13.6 \mathrm{~mm}$.

The second step is defining the internal geometry that represents the equipment. To create a thermal model of the internal equipment in the Thermal Desktop, all equipment was represented as cylindrical or box shapes. Each piece of equipment has a thickness of $5 \mathrm{~mm}$, heat capacity of $C_{p}=921 \mathrm{~J} / \mathrm{kgK}$, and thermal conductivity of $\mathrm{k}$ $=155 \mathrm{~W} / \mathrm{mK}$ which approximates all equipment to aluminum [25]. Fig. 3 shows the final view of the ESEO spacecraft geometry in the Thermal Desktop.

Nine nodes were defined for each panel, coming to a total of 81 nodes for the external structural and solar panels. Six nodes were defined for each internal equipment to create a total of 126 nodes and the MultiLayer Insulation (MLI) was modeled with 36 nodes. The numerical model has a whole of 243 nodes. Three types of nodes can be identified in the model: diffusion, arithmetic, and boundary nodes. The satellite is represented by 207 diffusion nodes and 36 arithmetic ones. Some experience is needed to determine the suitable number of nodes for each element (grid sensitivity analysis). In general, more nodes lead to higher resolution in the results. At the same time, increasing the number of nodes will increase the complication of the model and the time needed to build and run the model. Once a well-defined model is settled and initial conditions are specified, steady-state and transient computations can be obtained for all nodes over the chosen time interval.

This analysis is carried on Thermal Desktop (TD) software, which is capable of either finite difference or finite element investigations [37] with/without graphical interfaces. These graphical interfaces include a nongeometric sketchpad-style Sinaps and the geometry-based Thermal Desktop with its companion modules RadCAD and FloCAD [38].

The analysis starts with gathering enough infor-mation about satellite equipment nominal operation temperature ranges and predicted heat dissipation. Thermal boundary conditions for the post-mission phase must be identified, including spacecraft altitude, orbital parameters, and orientation relative to the Sun and Earth.

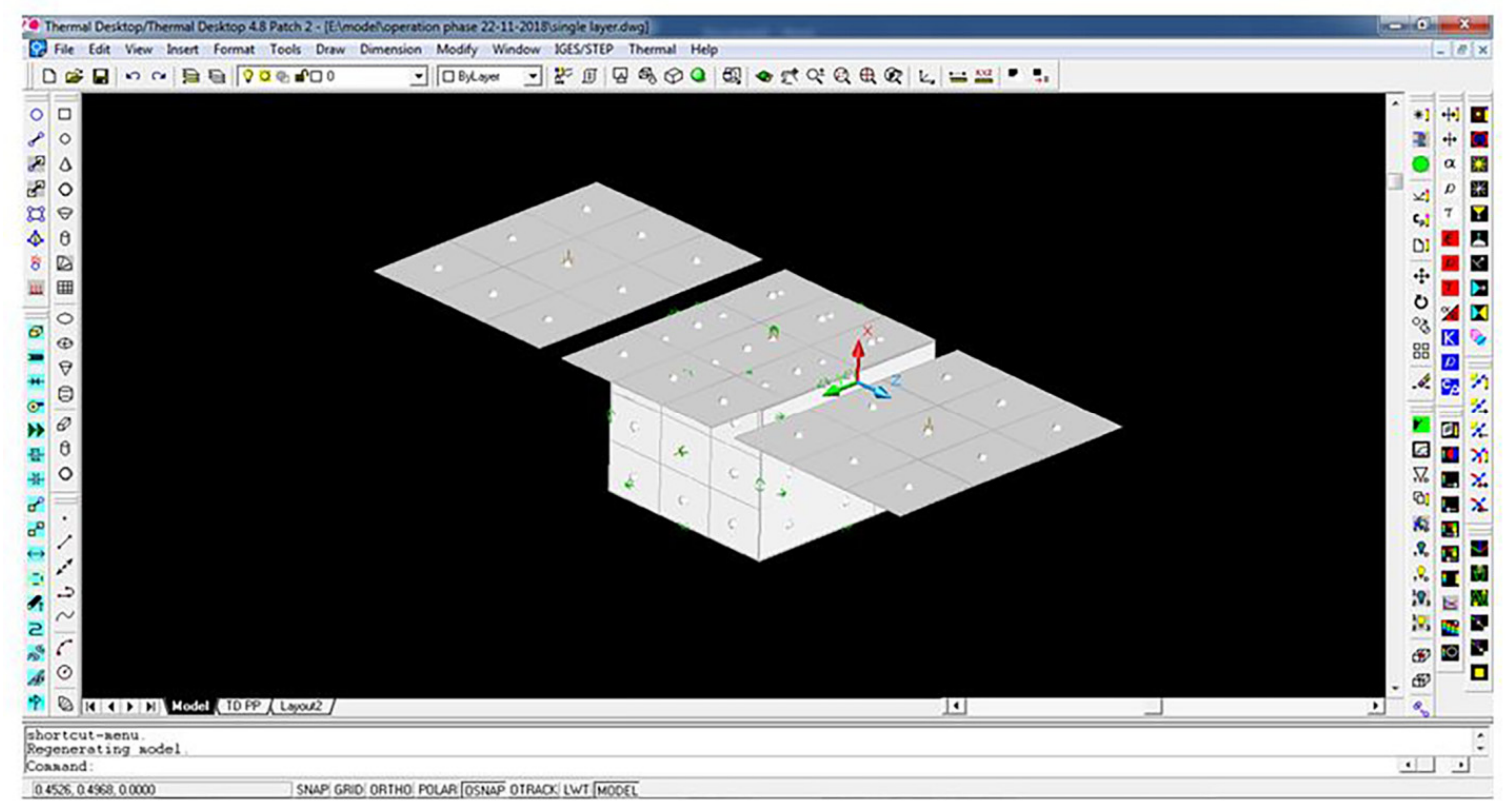

Fig. 3: Screenshot of ESEO geometrical model in Thermal Desktop 


\subsection{Boundary and Operating Conditions}

The orbital parameters define the location of the satellite relative to the Earth and Sun as presented in Table A.2. The external fluxes that encounter a satellite are solar, albedo, and planet Infra-Red (IR). Solar flux varies throughout the year because of the varying distance between the earth and sun because of the eccentricity of Earth's orbit. It is assumed that the solar flux is 1371 $\mathrm{W} / \mathrm{m}^{2}$ as a mean value in our study. Albedo fraction (AF) is defined as a fraction of the incoming solar radi-ation reflected by the Earth's surface. It can vary between 0.18 and 0.55 depending on satellite orientation and orbital parameters. For this analysis, a constant va-lue of 0.3 for AF is chosen [41]. The absorbed solar radiation by the earth is reemitted as a long-wave, called IR radiation [42]. The IR energy radiated by the Earth varies with season, latitude, the local, and the covering clouds. For most practical purposes, it is assumed that the Earth radiates IR with a constant intensity of $237 \mathrm{~W} / \mathrm{m}^{2}$ [2].

The internal components consume electrical power which is converted to heat. The entire internal heat dissipation in this stage for spacecraft equipment is 155.28 W. Table A2 shows dissipated heat for each piece of equipment in Watts.

The operating temperature limits of satellite components are usually determined by the manufacturer as given in Table 4.

Table 4 Operating temperature ranges for satellite elements

\begin{tabular}{|l|l|l|l|}
\hline Component & $\operatorname{Tmin}\left[{ }^{\circ} \mathrm{C}\right]$ & $\operatorname{Tmax}\left[{ }^{\circ} \mathrm{C}\right]$ & Ref. \\
\hline Main structure & -40 & +85 & {$[20]$} \\
\hline Solar cells & -100 & +100 & {$[20]$} \\
\hline Electronics & -20 & +60 & {$[43]$} \\
\hline Battery & -20 & +40 & {$[44]$} \\
\hline
\end{tabular}

The thermo-physical properties for structural panels, solar panels, and internal equipment are defined in Table A3, Table A4, and Table A5 respectively. The optical properties of the internal satellite components and inner faces of structural panels were chosen to have the surface finish of polished aluminum with an emissivity of 0.05 and absorptivity of 0.15 [31]. The external optical properties were selected as presented in Table 5.

\section{RESULTS AND DISCUSSIONS}

\subsection{First Analysis -Single Mode}

The single-mode analysis consists of having distinctive dissipated heat with time in both sun tracking and nadir pointing scenarios. The boundary conditions were constant and non-chained radiative cases were studied.

The external heat flux (solar, albedo, and planetary IR) along one orbit impinging the external faces (6 structure and 3 solar panels) for 81 nodes at sun pointing and nadir pointing modes of operation are calculated by Thermal Desktop. The results are compared with the corresponding results obtained by ESATAN-TMSs analyses [25]. The behavior of the external fluxes on the spacecraft is mainly affected by the orientation changing during the orbit.

Node 10 is located on the solar panel which is presented here as a sample of the results obtained. Fig. 4 demonstrates the time evolution of the heat fluxes on the external faces of the solar panel $+\mathrm{X}$ along one orbit at sun pointing (left) and nadir pointing ( right ) modes of operation respectively. when solar panel $+\mathrm{X}$ is facing the Sun (Fig. 5A (left)) the solar flux is maximum, while it tends to be zero when pointing to nadir as shown in Fig 5A (right).

The albedo is dependent on solar flux. IR depends on the view factor $F_{i j}$ between the spacecraft and the Earth. Node 50 located on the structural panel $+\mathrm{Y}$ is presented as a sample of the structural panel. Fig. 5 shows the external fluxes on structural panel $+Y$.

By examination of all results, it is found that no major deviations in heat fluxes have been recorded between all nodes of the same surface calculated with both softwares.

\subsection{Post-Mission Phase}

Transient thermal analysis of the Thermal Desktop model was run and tested for different time intervals (No. of orbital periods). It was found that a time of 4 orbital periods is an adequate amount of time for the satellite temperature to reach steady-state conditions. The temperatures of solar panels, structural panels, and all internal satellite components were examined.

Fig. 6 through Fig. 13 show the temperature variation of the central node of each panel for the postmission stage as analyzed by TD. The central nodes have been chosen as the representative of the average condition of the whole surface [35]. Results show that the temperature variations are periodic for each orbit.

The upper limit temperature occurs when the spacecraft faces all three external fluxes-solar, albedo, and IR. Then, the spacecraft goes into the shadow and all spacecraft temperatures start to drop off as a result of the absence of the solar and albedo fluxes. As the spacecraft leaves the shadow, the temperature begins to rise.

Table 5 External Optical Properties

\begin{tabular}{|l|l|l|l|l|l|}
\hline Material & Panel & Type & $\alpha$ & $\varepsilon$ & Ref. \\
\hline MLI & Panels 1,3,4,6 & Insulation & 0.55 & 0.78 & {$[25]$} \\
\hline Aeroglaze A276 white paint & Panel 2 & Coating & 0.26 & 0.88 & {$[42]$} \\
\hline Teflon Aluminized 1 mm & Panel 5 & Radiator & 0.14 & 0.6 & {$[33]$} \\
\hline Silver Teflon & Solar panels front side & Tape & 0.08 & 0.78 & {$[25]$} \\
\hline Solar cells & Solar panels front side & Cells & 0.92 & 0.85 & {$[25]$} \\
\hline AMJ-750-LSBU & Solar panels back side & Coating & 0.76 & 0.81 & {$[25]$} \\
\hline
\end{tabular}


Fig. 6 illustrates the temperature variation for the solar panels in four cycles. The temperature change (between the extreme high and low levels) of the $+\mathrm{X}$ solar panel is $75{ }^{\circ} \mathrm{C}(-10$ to 65$)$ which is less than the change in temperature $\left(100{ }^{\circ} \mathrm{C}(-50\right.$ to 50$\left.)\right)$ faced by $+Z$ and $-Z$ solar panels. The maximum heat input is received by the solar panel $+X$ because this panel is fixed on the structural panel $+\mathrm{X}$ and receives heat flux dissipated from the internal components of $68.04 \mathrm{~W}$ from AMST and Gyro in addition to external heat flux.

\section{Thermal Desktop}

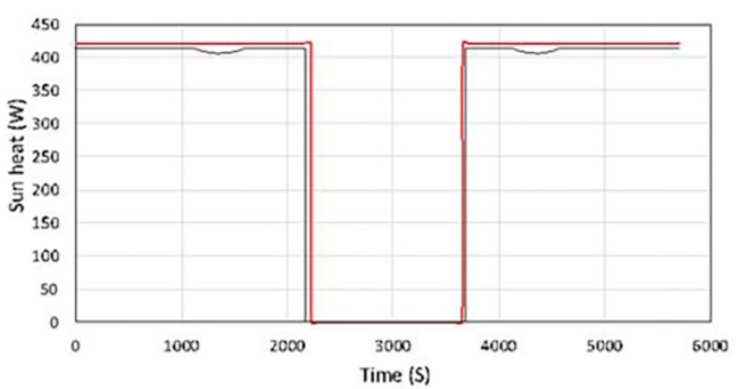

A: Solar heat (Sun pointing)

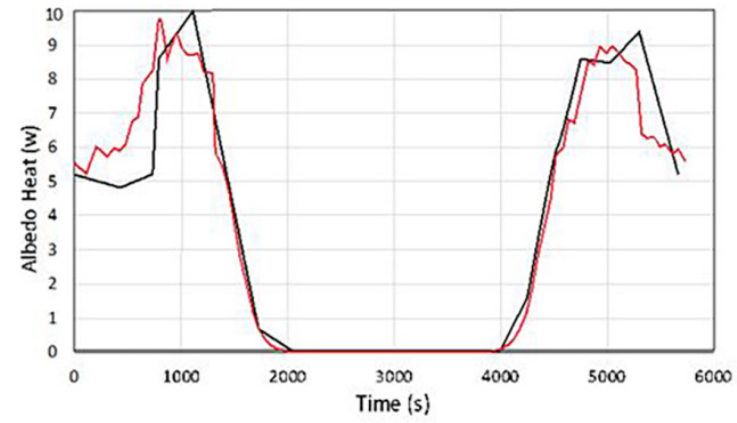

B: Albedo heat (Sun pointing)

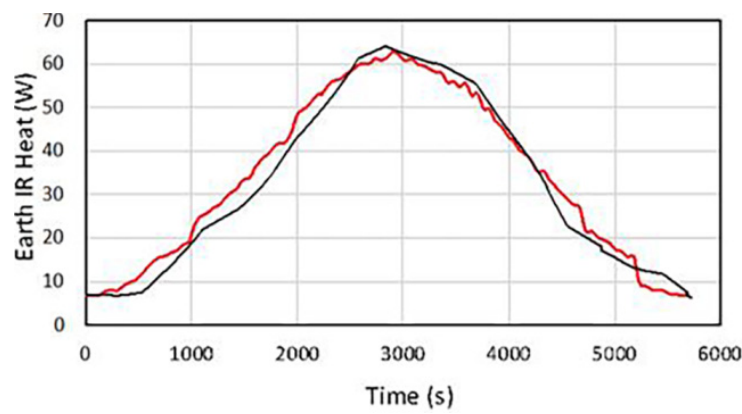

C: IR heat (Sun pointing)

Fig. 4: External heat fluxes on solar panel $+X$ as predicted by ESATAN and Thermal Desktop (node 10)

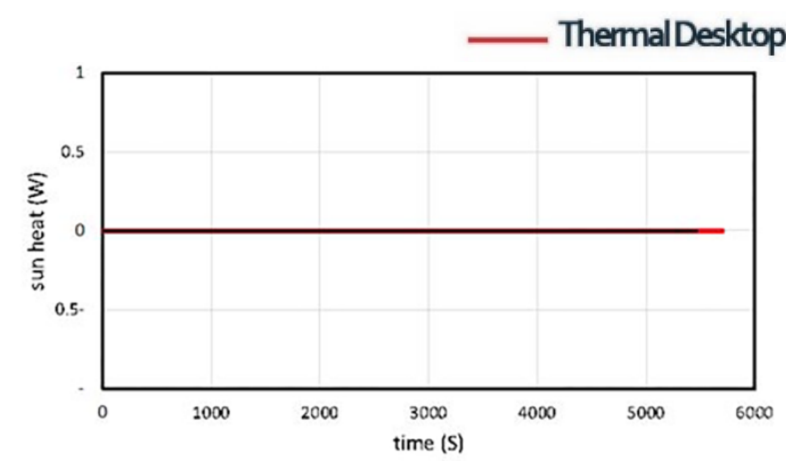

A: Solar heat (Sun pointing)
FME Transactions
The difference in heat input received by the panel $-\mathrm{Z}$ and $+X$ is caused by the change in surface area and view factors. All solar panels function inside their required limits $\left(-100\right.$ to $\left.+100^{\circ} \mathrm{C}\right)$.

The temperature experienced for all structural panels is shown in Fig. 7. The maximum and minimum temperatures for all panels are $25{ }^{\circ} \mathrm{C}$ and $16{ }^{\circ} \mathrm{C}$ respectively. All panels work within their required limits $\left(-40\right.$ to $\left.+85^{\circ} \mathrm{C}\right)$.

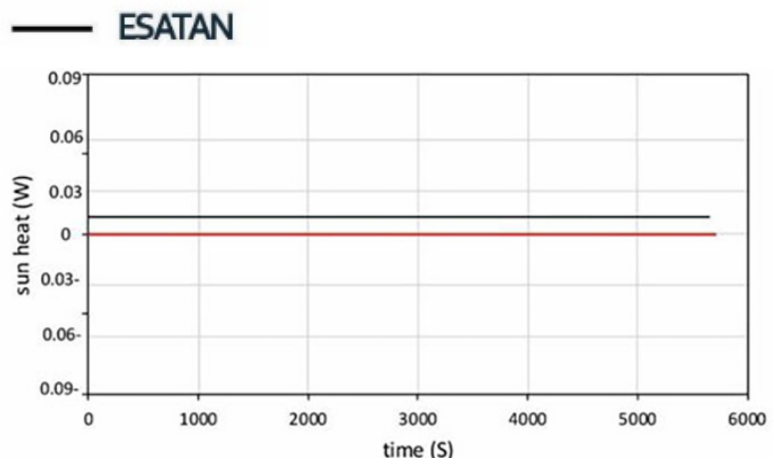

D: Solar heat (Nadir pointing)

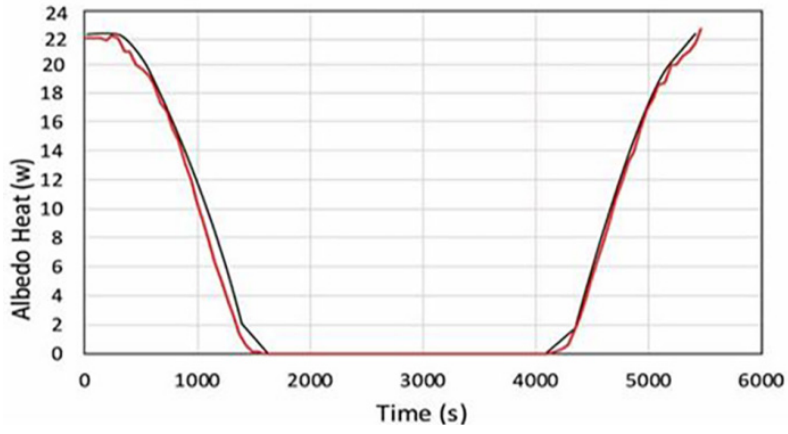

E: Albedo heat (Nadir pointing)

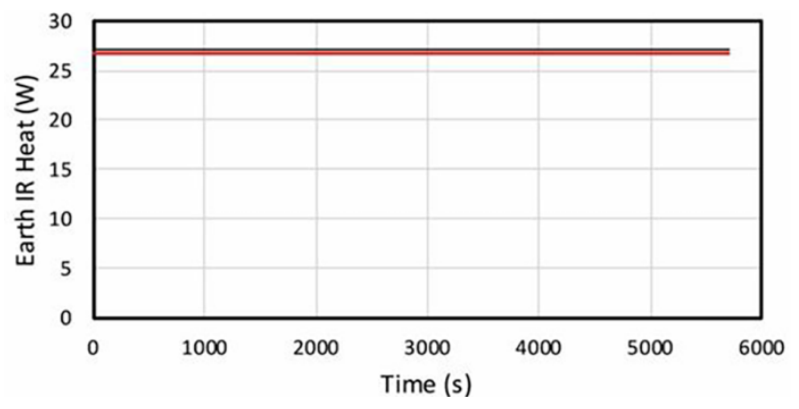

F: IR heat (Nadir pointing)

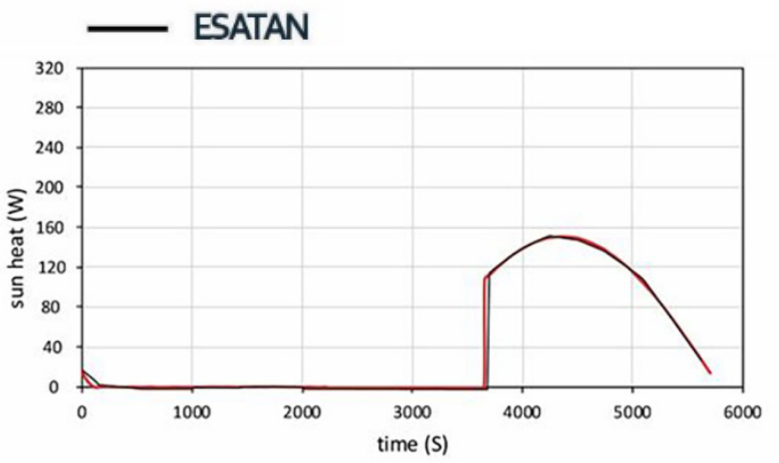

D: Solar heat (Nadir pointing) 


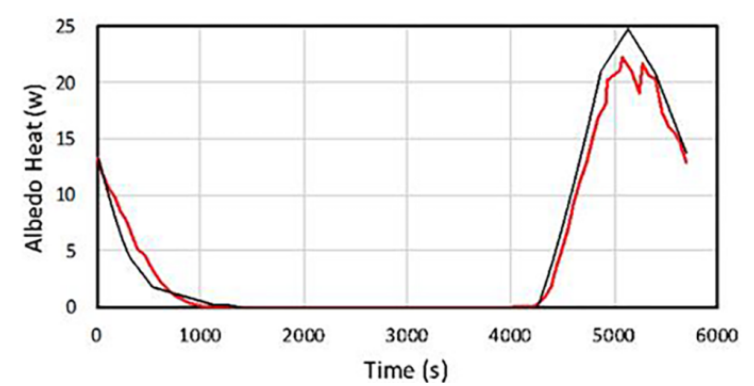

B: Albedo heat (Sun pointing)

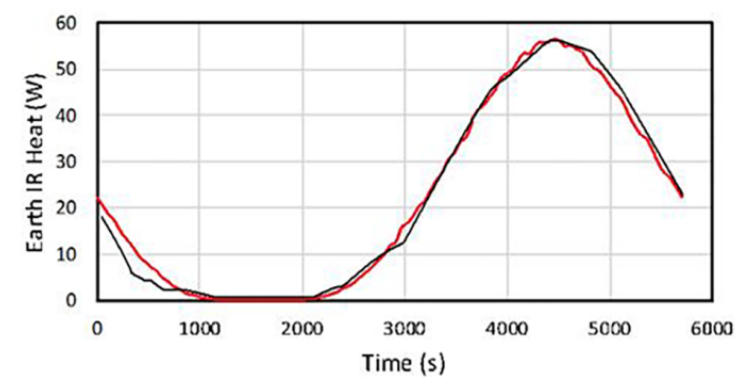

C: IR heat (Sun pointing)

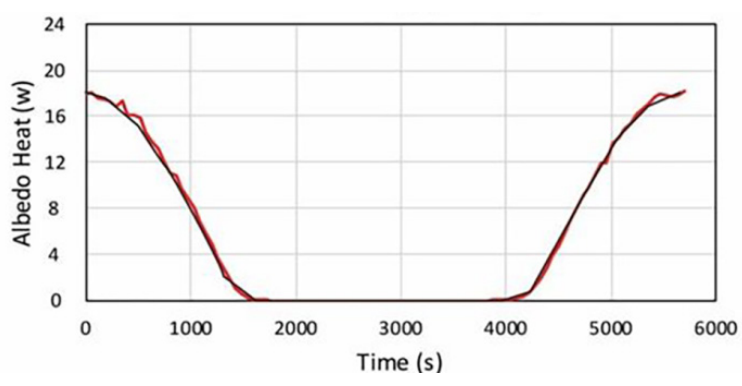

E: Albedo heat (Nadir pointing)

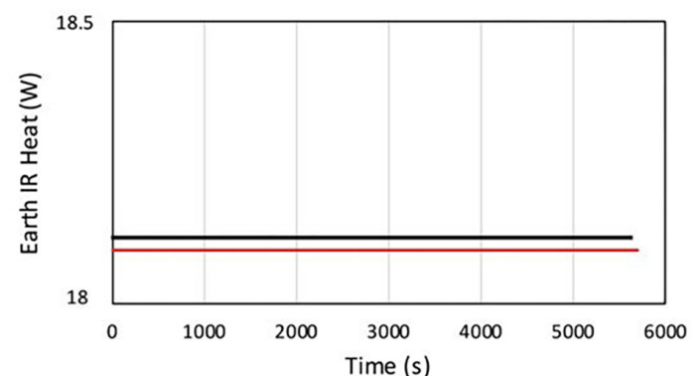

F: IR heat (Nadir pointing)

Fig. 5 External heat fluxes on structural panel $+Y$ as predicted by ESATAN and Thermal Desktop (node 50).

Panels $1(+\mathrm{X})$ and $5(-\mathrm{Y})$ have the maximum temperature due to high external heat fluxes and high internal heat dissipation of internal components (68.04 $\mathrm{W}$ and $26.06 \mathrm{~W}$ for panels 1 and 5 respectively). Panel 2 $(+\mathrm{Y})$ has the lowest maximum temperature due to low internal heat dissipation of internal component $(2.16 \mathrm{~W})$ and low external heat flux calculated in section 4.1.

Analyzed results show that external heat flux is more effective than internal component heat dissipation. Fig. 8 to Fig. 13 illustrate the temperature variation for all spacecraft equipment fixed on all structural panels. The temperature variations on equipment match their attached panel's temperature. The battery has the smallest temperature range that is used to be the design limits of all internal components $\left(-20\right.$ to $\left.+40{ }^{\circ} \mathrm{C}\right)$. The results confirm that all equipment normally works within required limits. Finally, the TCS accomplishes the temperature requirements for all spacecraft elements.

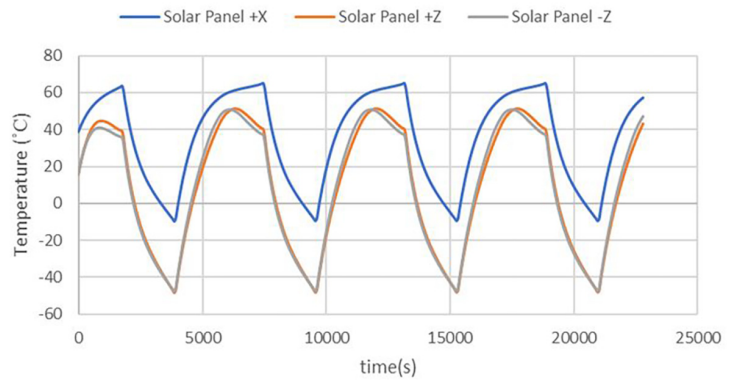

Fig. 6: Solar panels temperature change.

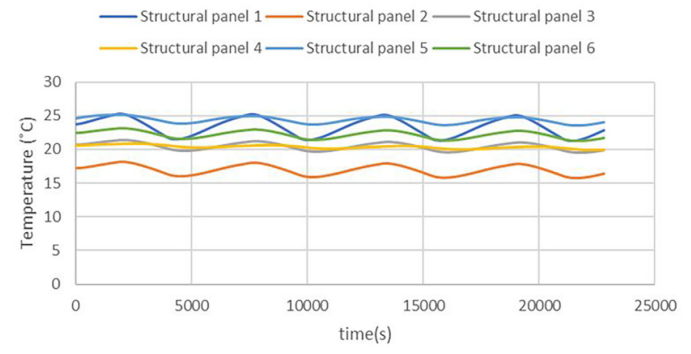

Fig. 7: Structural panels temperature change.

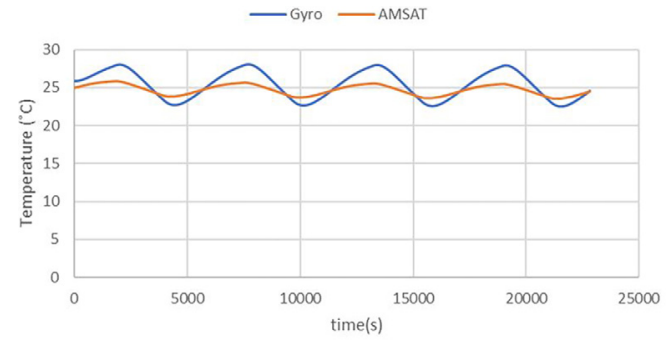

Fig. 8: Equipment temperature change on panel one

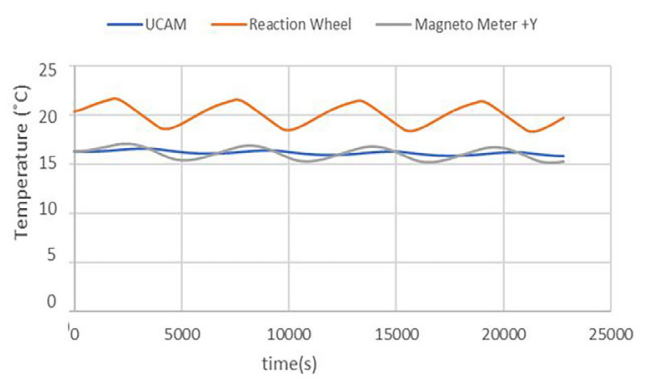

Fig. 9: Equipment temperature change on panel two

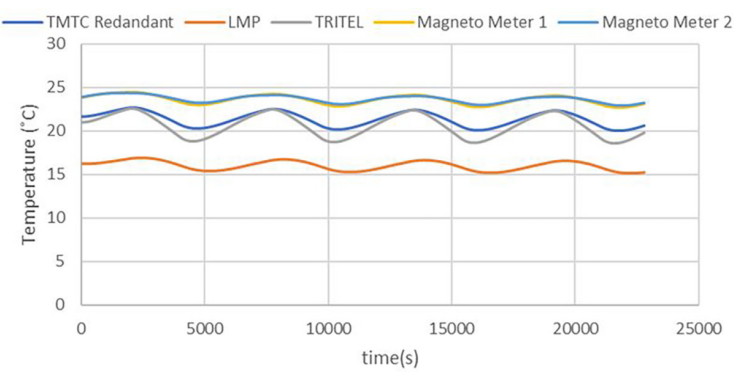

Fig. 10: Equipment temperature change on panel three.

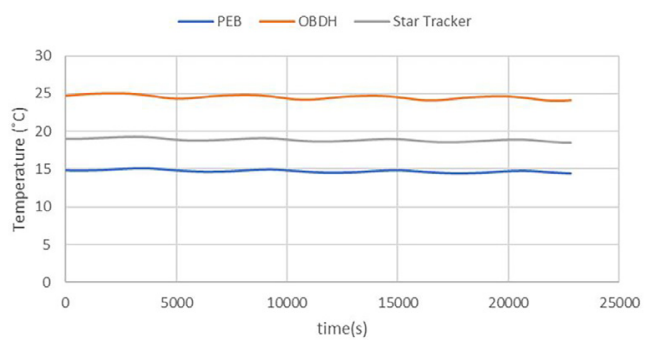

Fig. 11: Equipment temperature change on panel four. 


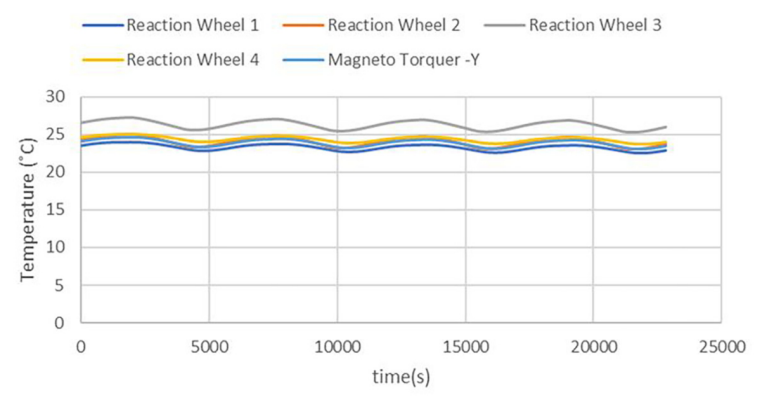

Fig. 12: Equipment temperature change on panel five.

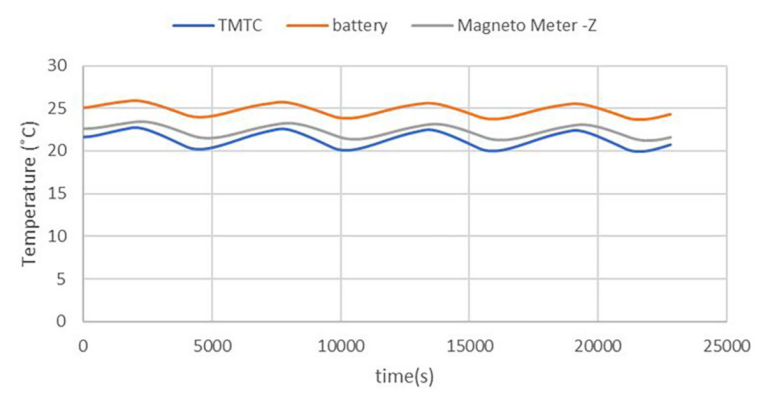

Fig. 13 Equipment temperature change on panel six.

\section{CONCLUSION}

A detailed thermal model for ESEO satellite in the postmission phase has been created using Thermal Desktop software. Some results were compared with published data for the external radiation absorbed by the satellite. The results showed that the passive thermal control system was able to meet requirements and maintain component temperatures and panels within their design limits. From this study we come to the following conclusion:

- Satellite thermal design is an iterative process and the model is subsequently modified to improve the thermal performance of the spacecraft.

-Equipment distribution, emissivity, absorptivity, and MLI placement are the main parameters that can be varied to change the temperature distribution.

-The spacecraft internal equipment location, physical and optical properties were taken into consi-deration to accomplish the required component's thermal requirements.

-The results gathered from the simulation present that all spacecraft elements were kept within their margins.

-Comparison with a specialized thermal analysis software package (ESATAN-TMSs) verified the integrity of the results.

Finally, concerning future work, Thermal Vacuum Tests should be conducted in a vacuum chamber where the satellite (or equipment) is under vacuum and subjected to the worst hot and cold conditions including adequate margins. It is hoped that, this study aid future researchers in understanding the thermal design process and serves as a basis to perform a similar type of design and analysis using Thermal Desktop software.

\section{ACKNOWLEDGMENT}

The authors highly are grateful for the support of the STC and MTC in Egypt for their encouragement and support.

\section{REFERENCES}

[1] M. Donabedian, "Spacecraft Thermal Control Handbook, Volume II: Cryogenics," 2004. DOI: 10.2514/4.989148.

[2] P. Fortescue J. Stark, Spacecraft systems engineering, 3rd ed. John Wiley \& Son. Ltd., 2003.

[3] K. Oshima and Y. Oshima, "Analytical approach to the thermal design of spacecraft," Inst. Sp. Aeronaut. Sci. Tokyo., no. Report No. 419, 1968.

[4] C. Arduini, G. Laneve, and S. Folco, "Linearized techniques for solving the inverse problem in the satellite thermal control," Acta Astronaut., vol. 43, no. $9-10$, pp. $473-479$, 1998, DOI: $10.1016 / \mathrm{S} 0094-$ 5765(98)00180-5.

[5] I. Pérez-Grande, A. Sanz-Andrés, C. Guerra, and G. Alonso, "Analytical study of the thermal behavior and stability of a small satellite," Appl. Therm. Eng., vol. 29, no. 11-12, pp. 2567-2573, 2009, DOI: 10.1016/j.applthermaleng.2008.12.038.

[6] J. Gaite, A. Sanz-Andrés, I. Pérez-Grande, "Nonlinear analysis of a simple model of temperature evolution in a satellite," Nonlinear Dyn., vol. 58, no. $1-2$, pp. 405-415, 2009, DOI: $10.1007 /$ s11071009-9488-x.

[7] J. Gaite, "Nonlinear analysis of spacecraft thermal models," Nonlinear Dyn., vol. 65, no. 3, pp. 283300, 2011, DOI: 10.1007/s11071-010-9890-4.

[8] N. D. Anh, N. N. Hieu, and N. N. Linh, "A dual criterion of equivalent linearization method for nonlinear systems subjected to random excitation," Acta Mech., vol. 223, no. 3, pp. 645-654, 2012, DOI: $10.1007 / \mathrm{s} 00707-011-0582-\mathrm{z}$.

[9] N. D. Anh, V. L. Zakovorotny, N. N. Hieu, D. V. Diep, "A dual criterion of stochastic linearization method for multi-degree-of-freedom systems subjectted to random excitation," Acta Mech., vol. 223, no. 12 , pp. 2667-2684, 2012, DOI: $10.1007 /$ s00707-012-0738-5.

[10] N. D. Anh, N. N. Hieu, P. N. Chung, N. T. Anh, "Thermal radiation analysis for small satellites with single-node model using techniques of equivalent linearization," Appl. Therm. Eng., vol. 94, pp. 607-614, 2016, DOI: 10.1016/j.applthermaleng.2015. 10.139.

[11]E. Escobar, M. Diaz, and J. C. Zagal, "Evolutionary design of a satellite thermal control system: Real experiments for a CubeSat mission," Appl. Therm. Eng., vol. 105, pp. 490-500, 2016, DOI: 10.1016/j.applthermaleng.2016.03.024.

[12]J. Gaite and G. Fernández-Rico, "Linear approach to the orbiting spacecraft thermal problem," $J$. Thermophys. Heat Transf., vol. 26, no. 3, pp. 511522, 2012, DOI: 10.2514/1.T3748.

[13]A. S. Gohardani, "Small satellites: Observations and considerations," AIAA Aerosp. Sci. Meet. 2018, no. 210059 , pp. 1-12, 2018, DOI: $10.2514 / 6.2018-$ 1937.

[14]"Website of Surrey Space Center, Small Satellite Title,” 2020. http://www.ee.surrey.ac.uk/SSC/ SSHP (accessed Sep. 19, 2020). 
[15]"NASA, What are SmallSats and CubeSats," 2020. https:/www.nasa.gov/content/what-are-smallsatsand-cubesats (accessed Sep. 19, 2020).

[16] V. Baturkin, "Micro-satellites thermal control Concepts and components," Acta Astronaut., vol. 56, no. 1-2, pp. 161-170, 2005, DOI: 10.1016/j.actaastro.2004.09.003.

[17]M. Swartwout and C. Jayne, "University-Class Spacecraft by the Numbers: Success, Failure, Debris. (But Mostly Success.)," Proc. AIAA/USU Conf. Small Satell. Conf. Small Satell., no. August, 2016, [Online]. Available: http://digitalcommons. usu.edu/smallsat/2016/ TS13Education/1.

[18] M. Swartwout, "Reliving 24 Years in the Next 12 Minutes: A Statistical and Personal History of University-Class Satellites," Proc. 32nd AIAA/USU Conf. Small Satell., pp. 1-20, 2018, [Online]. Available:https://digitalcommons.usu.edu/cgi/viewc ontent.cgi?article $=4277 \&$ context $=$ smallsat.

[19] S. Czernik, "Design of the Thermal Control System for Compass-1," Diploma thesis, no. University of Applied Sciences Aachen, 2004.

[20]L. Jacques, "Thermal Design of the Oufti-1 nanosatellite," MSc. thesis, no. Centre Spatial de Liège, 2009.

[21]Dai Q. Dinh, "Thermal Modeling OF Nanosat," MSc. thesis, no. San José State University, 2012.

[22] M. Bulut, O. R. Sozbir, and N. Sozbir, "Thermal Control of Turksat 3U Nanosatellite Thermal Control of Turksat 3U Nanosatellite," 5th Int. Symp. Innov. Technol. Eng. Sci., no. October 2017.

[23] "ESA, TurkSat-3USat." https://directory.eoportal. org/web/ eoportal/satellite-missions/t/turksat-3usat (accessed Sep. 19, 2020).

[24]M. M. Garzon, "Development and Analysis of thermal Design for the OSIRIS-3U Cubesat," $M S c$. thesis, no. The Pennsylvania State University, 2012.

[25]M. J.-L. C. Poucet, "Phase-B Thermal Control Subsystem Design for the ESEO Satellite," Msc. thesis, no. POLITECNICO DI MILANO, 2012.

[26]D. F. da Silva, I. Muraoka, and E. C. Garcia, "Thermal control design conception of the Amazonia-1 satellite," J. Aerosp. Technol. Manag., vol. 6, no. 2, pp. 169-176, 2014, DOI: 10.5028/jatm.v6i2.320.

[27]M. R. Ali, "Design and Implementation of Ground Support Equipment for Characterizing the Performance of XPOD and CNAPS \& Thermal Analysis of CNAPS Pressure Regulator Valve," MSc. thesis, no. Department of Aerospace Engineering University of Toronto, 2009.

[28] J. M. Elliott, U. of T. (Canada)., and A. S. and Engineering., "The thermal design and analysis of the CanX-4/-5 and NEMO-AM nanosatellites.," 2014.

[29]C.-4\& 5 ESA, "(Canadian Advanced Nanospace eXperiment-4\&5),” 2020. https://earth.esa.int/web/ eoportal/satellite-missions/c-missions/canx-4-5 (accessed Sep. 19, 2020).
[30]B. S. Cotten, "Design, Analysis, Implementation, and Testing of the Thermal Control, and Attitude Determination and Control Systems for the CANX7 Nanosatellite Mission," MSc. thesis, no. University of Toronto, 2014.

[31]E. Verheire, V. Van der Haegen, F. Desplentere, and P. Testani, "Thermal analysis of the QARMAN re-entry satellite," MSc. thesis, no. von Karman Institute for Fluid Dynamics Aeronautics / Aerospace Department, p. 142, 2015.

[32] T. Van Boxtel, "Thermal modeling and design of the DelFFi satellites," MSc. thesis, no. Delft University of Technology, p. 190, 2015, [Online]. Available: http://resolver.tudelft.nl/uuid:a77149c94fd0-4cdc-ade9-6c5aca719a64.

[33]K. E. Boushon, "Thermal analysis and control of small satellites in low Earth orbit," MSc. thesis, no. MISSOURI UNIVERSITY OF SCIENCE AND TECHNOLOGY, 2018, [Online]. Available: https://scholarsmine.mst.edu/masters_theses/7755.

[34] J. R. Kopacz, R. Herschitz, and J. Roney, "Small satellites an overview and assessment," Acta Astronaut., vol. 170, no. January, pp. 93-105, 2020, DOI: 10.1016/j.actaastro.2020.01.034.

[35] S. Corpino, M. Caldera, F. Nichele, M. Masoero, and N. Viola, "Thermal design and analysis of a nanosatellite in low earth orbit," Acta Astronaut., vol. 115, pp. 247-261, 2015, DOI: 10.1016/j.actaastro.2015.05.012.

[36] M. F. Diaz-Aguado, J. Greenbaum, W. T. Fowler, and E. G. Lightsey, "Small satellite thermal design, test, and analysis," Model. Simulation, Verif. Spacebased Syst. III, vol. 6221, no. 512, p. 622109, 2006, DOI: $10.1117 / 12.666177$.

[37] M. Bulut and N. Sozbir, "Analytical investigation of a nanosatellite panel surface temperatures for different altitudes and panel combinations," Appl. Therm. Eng., vol. 75, pp. 1076-1083, 2015, DOI: 10.1016/j.applthermaleng.2014.10.059.

[38]B. A. Cullimore, S. G. Ring, and D. A. Johnson, "SINDA/FLUINT User's Manual Version 5.8," vol. 4, no. June 2015, DOI: 10.1108/175614111111 67854.

[39]R. Karam, Satellite Thermal Control for Systems Engineers. 1998.

[40]B. Anderson, C. Justus, and G. Batts, "Guidelines for the selection of near-earth thermal environment parameters for spacecraft design," Nasa TM-2001211221, no. October 2001, p. 32, 2001, [Online]. Available: http://www.dept.aoe.vt.edu/ cdhall/ courses/aoe4065/NASADesignSPs/tm211221.pdf.

[41] C. B. Vanoutryve, "A thermal analysis and design tool for small spacecraft," MSc. thesis, no. San Jose State University, 2008.

[42]D. G. Gilmore, Spacecraft thermal control handbook. Volume I. 2002.

[43] M. Day, "30 Years of Commercial Components In Space: Selection Techniques Without Formal Qualification," in 13th Annual AIAA/USU 
Conference on Small Satellites. SSC99-IIA-2, 1999, pp. 1-8, [Online]. Available: http://www.ee. surrey.ac .uk/EE/CSER/UOSAT.

[44] “BST BAT-100,” Berlin Space Technologies. 2020, Accessed: Sep. 19, 2020. [Online]. Available: https://www.berlin-space-tech.com/wpcontent/uploads/2020/07/PFR-PR10-Battery-FlyerV1.00-.pdf.

\section{NOMENCLATURE}

\section{Abbreviations}

ADCS Attitude determination and control System

ESA European Space Agency

ESEO European Student Earth Orbiter

FDM Finite Difference Method

FEM Finite Element Method

IR Infra-Red

LET Linear Energy Transfer

LEO Low Earth Orbit

LMP Langmuir plasma diagnostic probe

LTAN Local time of ascending node

MLI Multi-Layer Insulation

MTC Military Technical College

NASA National Aeronautics and Space

Administration

SFL Space Flight Laboratory

STC Space Technology Center

TCS Thermal Control Subsystem

WCC Worst-Case Cold

WCH Worst-Case Hot

\section{Symbols}

\section{Ai Nodal area $\left[\mathrm{m}^{2}\right]$}

$d x \quad$ The distance between two adjacent nodes

$F_{i j} \quad$ The view factor between nodes $\mathrm{i}$ and $\mathrm{j}$

$\mathrm{k} \quad$ The thermal conductivity of the material

$K_{i j} \quad$ conductive heat exchange factor between nodes $\mathrm{i}$ and $\mathrm{j}[\mathrm{W} / \mathrm{K}]$

$m_{i} c_{i} \quad$ Thermal mass of node $\mathrm{i}[\mathrm{J} / \mathrm{K}]$

Q Amount of heat transferred rate [W]

$R_{i j} \quad$ Radiative heat exchange factor between nodes $\mathrm{i}$ and $\mathrm{j}\left[\mathrm{W} / \mathrm{K}^{4}\right]$

$\mathrm{T}$ Temperature $\left[{ }^{\circ} \mathrm{C}\right.$ or $\left.\mathrm{K}\right]$

$\mathrm{t}$ Time [s or hr]

$\alpha \quad$ Absorptivity

$\varepsilon \quad$ Emissivity

$\sigma \quad$ Stefan-Boltzmann constant $\left[\mathrm{W} / \mathrm{m}^{2} \mathrm{~K}^{4}\right]$

\section{APPENDIX}

Table A5 Internal equipment thermo-physical properties
Table A1 Post-mission phase internal equipment heat dissipation

\begin{tabular}{|l|l|l|}
\hline Component & Panel & $\begin{array}{l}\text { Dissipated Heat } \\
\text { (W) }\end{array}$ \\
\hline AMSAT box & 1 & 54.84 \\
\hline TMTC redundant & 3 & 0 \\
\hline OBDH & 4 & 30 \\
\hline EPS PEB & 4 & 12 \\
\hline Star Tracker & 4 & 0 \\
\hline Reaction Wheel & 2 & 0 \\
\hline UCAM & 2 & 0 \\
\hline Magneto-Torquer $+Y$ & 2 & 2.16 \\
\hline RW 1 & 5 & 6 \\
\hline RW 2 & 5 & 6 \\
\hline RW 3 & 5 & 6 \\
\hline RW 4 & 5 & 6 \\
\hline Magneto-Torquer-Y & 5 & 2.16 \\
\hline TRITEL S & 3 & 0 \\
\hline TMTC box & 6 & 12 \\
\hline Gyro box & 1 & 13.2 \\
\hline Magnetometer 1 & 3 & 1.44 \\
\hline Magnetometer 2 & 3 & 1.44 \\
\hline EPS Battery & 6 & 0 \\
\hline LMP & 3 & 0 \\
\hline Magneto-Torquer-Z & 6 & 2.16 \\
\hline Total & & 155.4 \\
\hline
\end{tabular}

\section{Table A2 ESEO orbital parameters}

\begin{tabular}{|l|l|l|l|}
\hline $\begin{array}{l}\text { Keplerian orbital } \\
\text { parameters }\end{array}$ & Symbol & Units & value \\
\hline Altitude & $\mathrm{H}$ & $\mathrm{Km}$ & 520 \\
\hline Eccentricity & $\mathrm{E}$ & -- & 0 \\
\hline RAAN & $\Omega$ & Degrees & 47.7 \\
\hline Perigèe Argument & $\Omega$ & Degrees & 0 \\
\hline Inclination & $\mathrm{I}$ & Degrees & 97.48 \\
\hline Initial true anomaly & $\mathrm{Y}$ & degrees & 0 \\
\hline
\end{tabular}

Table A3 Solar panels thermo-physical properties [23]

\begin{tabular}{|l|l|l|l|l|}
\hline $\begin{array}{l}\text { Panel } \\
\text { No. }\end{array}$ & Material & $\begin{array}{l}\text { Density } \\
{\left[\mathrm{kg} / \mathrm{m}^{3}\right]}\end{array}$ & $\begin{array}{l}\text { Spec. } \\
\text { heat Cp } \\
{[\mathrm{J} / \mathrm{kg} \mathrm{K}]}\end{array}$ & $\begin{array}{l}\text { Cond- } \\
\text { uctivity } \\
{[\mathrm{W} / \mathrm{m} \mathrm{K}]}\end{array}$ \\
\hline Panel 1 & Aluminum & 522.878 & 921 & 155 \\
\hline Panel 2 & Honeycomb & 725.701 & 921 & 97.857 \\
\hline Panel 3 & Honeycomb & 791.074 & 921 & 97.857 \\
\hline Panel 4 & Aluminum & 541.292 & 921 & 155 \\
\hline Panel 5 & Aluminum & 1177.37 & 921 & 155 \\
\hline Panel 6 & Honeycomb & 707.123 & 921 & 97.857 \\
\hline
\end{tabular}

Table A4 Solar panels Thermo-physical properties [23]

\begin{tabular}{|l|l|l|l|l|}
\hline Solar data & Material & $\begin{array}{l}\text { Density } \\
{\left[\mathrm{kg} / \mathrm{m}^{3}\right]}\end{array}$ & $\begin{array}{l}\mathrm{Cp} \\
{[\mathrm{j} / \mathrm{kg} \mathrm{K}]}\end{array}$ & $\begin{array}{l}\text { Conduct. } \\
{[\mathrm{W} / \mathrm{m} \mathrm{K}]}\end{array}$ \\
\hline Solar $+\mathrm{X}$ & Honeycomb & 503.953 & 921 & 97.85714 \\
\hline Solar $-\mathrm{Z}$ & Honeycomb & 503.953 & 921 & 97.85714 \\
\hline Solar $+\mathrm{Z}$ & Honeycomb & 503.953 & 921 & 97.85714 \\
\hline
\end{tabular}

\begin{tabular}{|l|l|l|l|l|}
\hline Component & Shape & Mass $[\mathrm{kg}]$ & Volume $\times 10^{-6}\left[\mathrm{~m}^{3}\right]$ & Density $\left[\mathrm{kg} / \mathrm{m}^{3}\right]$ \\
\hline AMSAT box & Box & 0.72 & 695 & 1035.98 \\
\hline TMTC redundant & Box & 4.61 & 836 & 5514.35 \\
\hline TMTC antenna $+X$ & Box & 0.12 & 198.12 & 605.69 \\
\hline OBDH & Box & 12 & 1445.31 & 8302.72 \\
\hline EPS PEB & Box & 8.4 & 1491.5 & 5631.91 \\
\hline Star Tracker & Box & 2.06 & 341.472 & 6032.7 \\
\hline TMTC antenna $-X$ & Box & 0.12 & 198.12 & 605.69 \\
\hline Reaction Wheel & Box & 0.96 & 2617.25 & 366.8 \\
\hline UCAM & Box & 0.72 & 222.405 & 3237.34 \\
\hline
\end{tabular}




\begin{tabular}{|l|l|l|l|l|}
\hline Magneto- Torquer + Y & cylinder & 1.44 & 12.4056 & 11607.66 \\
\hline TMTC Antenna + Y & Box & 0.12 & 198.12 & 605.69 \\
\hline Reaction Wheel 1 & Box & 1.8 & 977.75 & 1840.96 \\
\hline Reaction Wheel 2 & Box & 1.8 & 977.75 & 1840.96 \\
\hline Reaction Wheel 3 & Box & 1.8 & 977.75 & 1840.96 \\
\hline Reaction Wheel 4 & Box & 1.8 & 977.75 & 1840.96 \\
\hline Magneto- Torquer -Y & cylinder & 1.44 & 12.4056 & 11607.66 \\
\hline Tri-Tel S & Box & 1.44 & 110.39 & 13044.66 \\
\hline TMTC Antenna +Y & Box & 0.12 & 198.12 & 605.69 \\
\hline TMTC box & Box & 4.61 & 836 & 5514.53 \\
\hline Gyro box & Box & 1.8 & 386.32 & 4659.35 \\
\hline Magnetometer 1 & Box & 0.07 & 727.5 & 962.2 \\
\hline Magnetometer 2 & Box & 0.07 & 727.5 & 962.2 \\
\hline TMTC Antenna $+Z$ & Box & 0.12 & 198.12 & 605.69 \\
\hline EPS Battery & Box & 7.98 & 6035 & 1322.29 \\
\hline LMP & Cube & 0.96 & 192 & 5000 \\
\hline Magneto- Torquer -Z & cylinder & 1.44 & 12.4056 & 11607.66 \\
\hline TMTC antenna $-Z$ & Box & 0.12 & 198.12 & 605.69 \\
\hline
\end{tabular}

\section{МОДЕЛИРАЊЕ ТЕРМИЧКОГ УПРАВЉАЊА МАЛИМ САТЕЛИТОМ УНИВЕРЗИТЕТСКЕ \\ КЛАСЕ}

\section{И АНАЛИЗА У ФАЗИ НАКОН МИСИЈЕ}

\section{А. Елхефнави, А. Елмаихи, А. Елветеди}

Приказана је анализа термичког управљања малом свемирском летелицом у фази након мисије. Дистрибуција унутрашњих компонената сателита је модификована да би се испунили термички захтеви при коришћењу система пасивног термичког управ- љања. После мисије сателит ће користити АМСАТ заједница као транспондер, при чему ће се корисно оптерећење АМСАТ-а одржавати у пот-пуности најмање две године. Thermal Desktop соф-твер је уведен код поменуте летелице. Коначна ана-лиза предвиђа да систем пасивног термичког управљања одржава температуру свих елемената летелице у оквиру температурних граница. Вари-рање температуре код $+\mathrm{X}$ соларног панела износи $75^{\circ} \mathrm{C}$ што је мање него код $+Z$ и $-Z$ панела, а што је било $100^{\circ} \mathrm{C}$. Промена температуре опреме је у складу са променом температуре на панелима. Тачност података верификована је софтвер пакетом ESATAN-TMSs. 